\title{
Annual Report 2000-2001
}

\section{Improving Water and Land Resources Management for Food, Livelihoods and Nature}

Case Studies. Impacts and Outputs. Strategic Priorities 2000-2005

IWMI

631.7

G000

IWM

H38241

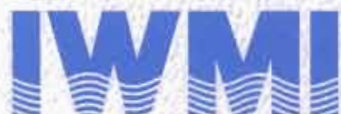

International Water Management Institute 


\section{CONTENTS}

Letter from the Board Chair

$$
\text { .. }
$$

Director General's Comment

...

IWMI's Strategy for 2000-2005

$\ldots$

The Year in Review: Events, Impacts and Research Results

\section{Research Themes and Case Studies*}

Integrated Water Management for Agriculture

Case Study: Water Use by Trees and Homestead Gardens in Irrigation Schemes

Sustainable Smallholder Land and Water Management Systems

Case Study: Low-cost Irrigation Technologies for Poverty Reduction

Sustainable Groundwater Management

Case Study: Using Monsoonal River Flows to Recharge Groundwater

Water Resources Institutions and Policies

Case Study: The Impact of Irrigation Management Transfer on African Smallholders

\section{Water for Health and Environment}

Case Study: Risks and Benefits of Wastewater Irrigation

\section{Donors}

Board of Governors

Financial Overview

Project Portfolio for 2001

Institute Staff

Publications 